\title{
THE RELATION OF PLASMA CHOLINESTERASES TO RESPONSE TO CLINICAL DOSES OF SUICCINYLCHOLINE*
}

\section{WERNER KaLOW, M.D.*}

MANY MUSCULAR RELAXANTs have been introduced during the past decade. Of all these relaxants, succinylcholine is the only drug with a tleeting action. This short duration of action has been ascribed to a rapid enzymatic destruction of succinylcholine in the body $(1,2)$.

The only enzyme which is known to destroy succinylcholine in man is plasma cholinesterase. There are several synonyms for plasma cholinesterase. The enzyme is also called serum cholinesterase, pseudo-cholinesterase, or non-specific cholnnesterase. The enzyme is distinctly different from acetyl-cholinesterase (or true cholinesterase) (3), which destroys acetylcholine in vivo and which is essential for various functions of the nervous system (4). Plasma cholinesterase is secreted by the liver into the blood (5), but its purpose is unknown. Besides being present in plasma and serum, this esterase occurs in various tissues (6), for instance in pancreas (7) and in the whte matter of the human brain (8). Plasma cholinesterase differs in its behaviour from species to species (9), and it does not occur in the plasma of all mammals (10).

We shall first consider the enzymatic destruction of succinylcholine in vitro. The enzymatic deactivation of succinylcholine is a hydrolysis and proceeds in two steps $(11,12)$. First, succinyldicholine is split into succinylmonocholine and choline. Succinylmonocholine is roughly one-twentieth as active in man as succinyldicholine $(13,14)$. In the"second step, which is a separate reaction, succinylmonocholine is split into succinc acid and choline.

Either succinyldicholine or succinylmonocholine combines with the esterase, and during this combination cholme is split off. The combining power between enzyme and drug (15) 1s, therefore, an important measure but it is sufficient at the moment to state that the apparent affinity ${ }^{1}$ between succinyldicholine and plasma cholinesterase is twenty times greater than the apparent affinity between succinylmonocholine and the enzyme (16). This is one of the reasons why the reaction occurs in two steps Figuratively speaking, if the enzyme has a free choice between succinyldicholine and succinylmonocholine, it prefers succinyldicholine However, the enzyme does not always have a free choice.

The rate of the enzymatic reaction depends on the following three factors: first, the intrinsic speed, second, the concentration of succinylcholine, third, the concentration of the esterase. We have to consider these three factors one by one.

First, there is the intrinsic speed with which the enzyme can handle succinyl. choline. This is expressed as a maximum rate of reaction and we state this as

'Presented at the Annual Meeting of the Canadian Anaesthetists' Society, Toronto, June 20, 1955

* Department of Pharmacology, University of Toronto

1I.e., the reciprocal of the Michaels constant. The constants were reported (16) as $13 \times 10^{-3}$ for succinyldicholine and $26 \times 10^{-2}$ for succinylmonocholine 
follows. A normal adult has about $3 \%$ litres of plasma. If these $31 \%$ litres have an average esterase activity, they are capable of hydrolysing either $120 \mathrm{mg}$. of succinyldicholine chloride per minute (17), or $60 \mathrm{mg}$. of succinylmonocholine chloride per minute. Thus, at maximum rates the first step of the reaction between plasma cholınesterase and succinylcholne is twice as fast as the second step (16).

Second, the concentrations of succinyldicholine $(16,17)$ and succinylmonocholine (16) influence the rate of reaction. The maximum speed of destruction of succinyldicholine is obtamed only if the enzyme is saturated with succinyldicholine, that is, at high concentrations of succinyldicholine. If the concentration of succinyldicholine is low, the rate of reaction is slow. The more its concentration rises, the faster it is destroyed until at very high concentrations the maximum rate is reached. The same rule holds for succinylmonocholine.

One cannot make a general statement saymg that the first step of the hydrolysis is faster than the second step. The ratio of reaction velocities depends on the concentrations of the two compounds. If the concentration of succinylmonocholine is very high and the concentration of succinyldicholine very low, then succinylmonocholıne would be hydrolysed faster. Therefore, there must be concentrations where succinyldichollne and succinylmonocholine are hydrolysed at the same rate, when both are simultaneously exposed to the esterase. A calculation shows that the first and the second steps of the reaction must be equally fast if the concentration of succinylmonocholine exceeds forty times the concentration of succinyldicholine ${ }^{2}$ Or vice versa, if they are hydrolysed at the same rate, the ratio of concentrations is always 1 to 40 regardless of the actual concentration of succinyldicholine. This is a key figure for our later deductions.

Third, the rate of reaction is influenced by the concentration of the enzyme, which is often called the plasma level of cholinesterase. The rate of reaction is proportional to the concentration of esterase (17); thus, doubling the esterase level causes the reaction to proceed twice as fast. It is important to notice that this rule also holds at low concentrations of succinylcholine when the reaction rate is slow.

The significance of these enzymological data can now be discussed. There is no reason to assume that the enzyme acts differently towards succinylcholine in vivo than it does in vitro. Thus the circulating plasma cholinesterase of the normal adult could destroy up to $120 \mathrm{mg}$. of succinylcholine chloride per minute. We can conclude that the plasma cholinesterase is an important factor for the deactivation of succinylcholine in the human body.

2The equation for competitive inhibition is frequently described in the enzymological literature (e g, F M Huennekens in Technique of Organic Chemistry, vol. VIII, edited by A Weissberger [New York Interscience Publishers Inc, 1953], Equation 41, p 572 and equation 65 , p. 586). For our calculation this equation was first written treating succinyld 1 choline as the substrate and succinylmonocholine as the inhibitor Thus, the first equation describes the rate of hydrolysis of succinyldicholine The second equation was set up treating succinyldicholine as the inhibitor, and calculating the rate of hydrolysis of the substrate succinylmonocholine If both these rates of hydrolysis are equal, the first and second equations can be combined to form a third equation By inserting numencal values for the Michaels constants and the maximum velocity into the third equation, the above mentioned ratio of concentrations was obtained. 
One can never reach the concentration of succinyldicholine in the circulating blood that would saturate the esterase and cause a maximum reaction rate. The esterase would act at only half the maximum rate if 1 to $2 \mathrm{gm}$. of succinylcholine were in the circulating plasma, and, also, this concentration is far in excess of practical limits. It follows that only a fraction of the available esterase can be active at any given time. We do not yet know the blood level of succinylcholine after injection, owing to the chemical difficulties of such a determination. We are, therefore, not sure how fast the circulating plasna cholinesterase acts in vivo, and whether we must expect that other factors contribute to the destruction of succinylcholine, such as the liver esterase. It has been found, however, that hardly any succinylcholine appears in the urine (18).

Although only a fraction of the available plasma cholnesterase will be occupied at any given moment by succinylcholine in vivo, the size of this fraction is proportional to the esterase level. In other words, the esterase does not act at its full capacity whether its level is high or low.

If one gives a slow constant intravenous drip of succinylchuline over long periods of time, a certain degree of relaxation will be achieved and maintained as long as the drip lasts (19). That means, the drip brings the plasma concentration of succinyldicholine to such a level that the esterase acts at a rate whereby just as much is destroyed per minute as one puts into the system. If the rate of drip is increased, the blood level will be higher, which causes the esterase to act faster, and a new equilibrium will be established. In .other words, the blood level adjusts itself so that input and destruction are balanced.

This equilibrium must be maintained also for succinylmonocholine. The concentration of succinylmonocholine shortly after the start of the drip is very low so that it is destroyed very slowly, its concentraton builds up, and correspondingly the destruction of succinylmonocholine becomes faster. Ultimately it will reach a level of concentration where its rate of formation is just as fast as its rate of destruction; in other words, succnylmonocholine will be removed just as fast as succinyldicholine is injected and destroyed. If the plasma cholinesterase is the only deactivating force, it follows that at equilibrium the plasma concentration of succinylmonocholine must be forty times as high as the concentration of succinyldicholine. Thus, from our present knowledge of the interaction between plasma cholinesterase and succinylcholine, we must predict that during slow intravenous infusion succinylmonocholine regularly accumulates.

When sufficient succinyldicholine was administered to achieve relaxation of: momentary duration, succinylmonocholine could not possibly reach an effective level. Between these two extremes of rapid injection and prolonged drip, all intermediate stages of accumulation of succinylmonocholine must be expected to occur.

No matter how effectively the plasria cholinesterase can attack succinylcholine in the blood, the drug in the body is not always exposed to the esterase. Very shortly after intravenous injection, a major portion of succinylcholine must have left the blood vessels to be distributed over the extracellular space. Figure il explains this conclusion. It shows a schematic cross-section of single muscle fibres and capillaries in between. A motor nerve with its end-plate is shown 
supplying one of the muscle fibres. After intravenous injection, the drug is carried by the blood into the capillaries. In order to reach the end-plate, the site of action of succinylcholine, the drug has to leave the capillaries and it must diffuse through the extracellular space. As is known from the rapid onset of action of succinylcholine, these processes of crossing the capillary walls and travelling through the extracellular space towards the end-plate must occur with great speed. The main driving force for these processes is probably the concentration gradient. The extracellular space outside the blood vessels is roughly three times as large as the blood volume. Thus, within a short time there must be more succinylcholine outside the blood than inside.

It is not very likely that the normal extracellular fluid contains much plasma cholinesterase. Ascitic fluid (20) and cerebrospinal fluid (21) have been shown

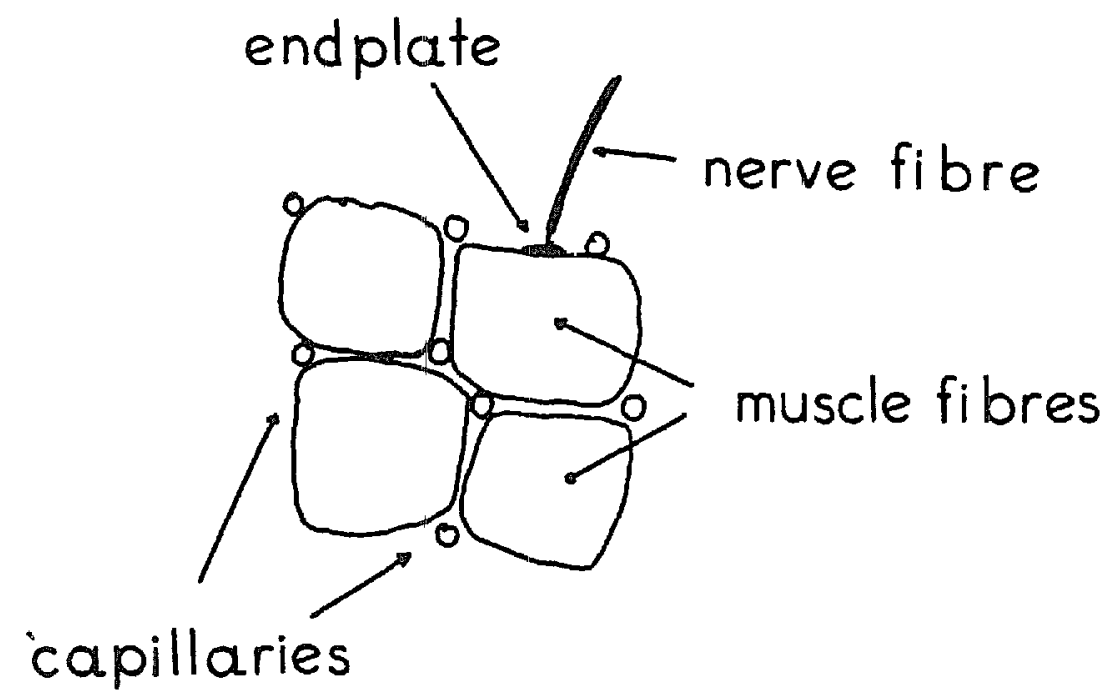

Figure 1. Schematic cross-section through single muscle fibres and capillaries. This figure demonstrates that a drug must leave the vascular bed and enter the extracellular fluid before it can reach the end-plate. Since the extravascular space is larger than the vascular bed, the drug becomes diluted and more of it must be outside the capillaries than inside. The figure was drawn after consultation with Dr. S. Bensley of the Department of Anatomy, University of Toronto.

to contain some, but very little, esterase. Thus, shortly after intravenous injection, a considerable portion of succinylcholine is in the extracellular space and thereby out of reach of the circulating esterase. In other words, the esterase guards the entrance to and the exit from the tissues but the esterase cannot be blamed for irregularities which might occur in the tissues, at the site of action of succinylcholine.

The foregoing theoretical deductions fit the following clinical experiences. First, the importance of the enzyme for the deactivation of succinylcholine has been confirmed by several observations. There are numerous reports of cases with a low esterase level where a prolonged apnoea after succinylcholine occurred $(2,22,23,24,25,26,27,28)$.

We can add here the description of some particularly instructive cases which were observed in Toronto. We had the opportunity to study three sera with 
extremely low esterase activity from patients who had reacted with prolonged apnoea after succinylcholine.

On repeated routine investigations these sera showed an esterase activity between 30 and 50 units; the average plasma contains 210 units. To our surprise, these esterases showed some unusual behaviour in addition to their low activity. (Figure 2 gives an example.) The activity was not equally reduced towards

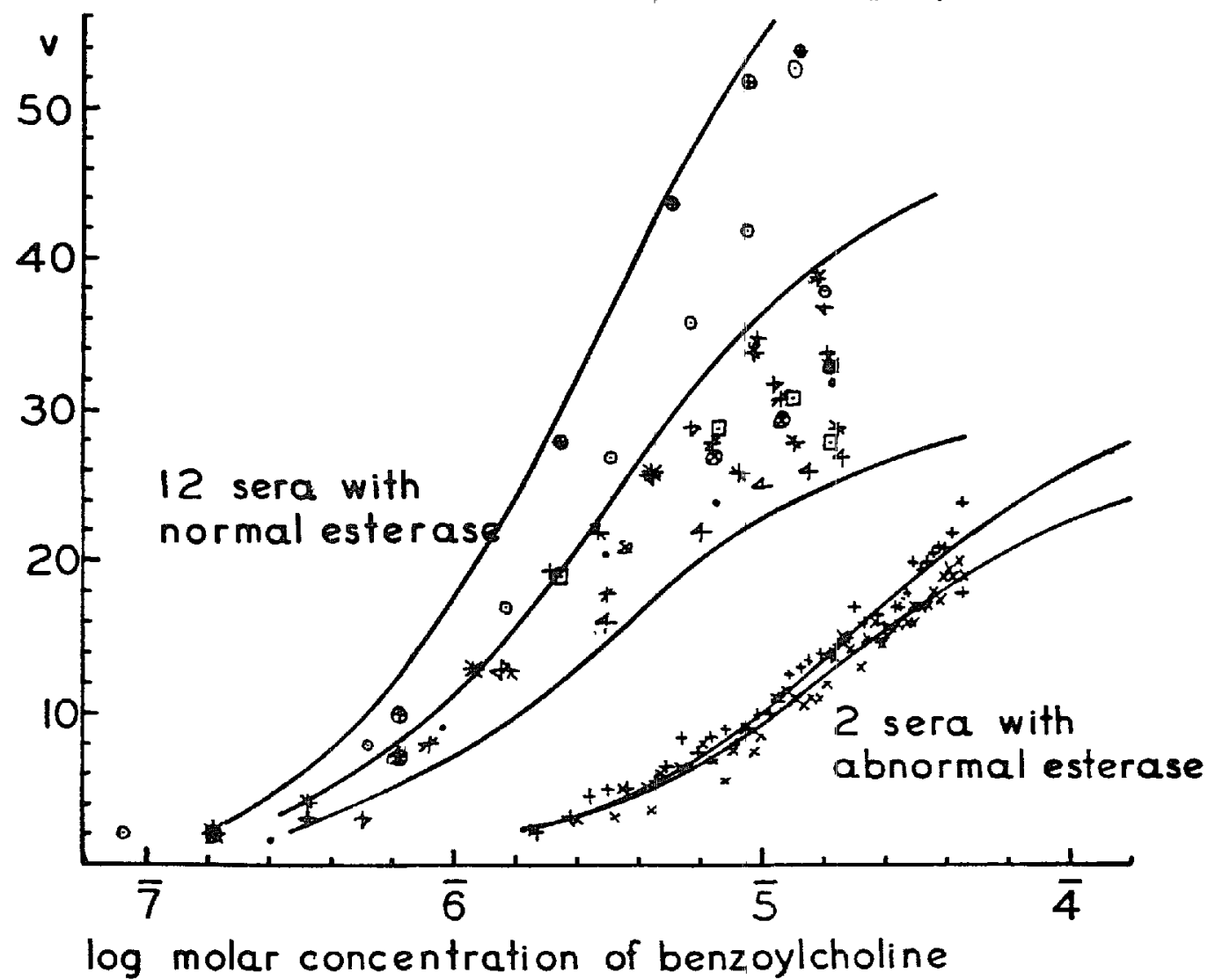

Figure 2. A contrast between normal and abnormal behaviour of human plasmacholinesterase. The rate of hydrolysis of benzoylcholine (determined by ultraviolet spectrophotometry) is plotted against log concentration of benzoylcholine. Experiments on different sera are designated by different symbols. The common type of variation between different sera causes the S-shaped curves to be more or less steep. The two abnormal curves are shifted horizontally. The abnormality has persisted for more than a year and is not confined to benzoylcholine. The hydrolysis of succinylcholine is not measurable. The presence of an unknown competitive inhibitor is excluded by dialyzing experiments.

various cholinesters, affinities were lower, and they were not so easily inhibited (for instance, by neostigmine). There were no signs of an unknown inhibitor. In short, there were changes which are hard to explain at the moment and which indicated a deeply distorted as well as a low esterase activity. Direct measurements revealed that these esterases split succinylcholine so slowly that no accurate data were obtained. ${ }^{3}$

One of these patients was anaesthetized by Dr. MacKay at the Toronto General Hospital. The patient was 6 feet tall, weighed. 180 pounds, and was in good

3The enzymatic hydrolysis in the Warburg apparatus was considerably slower than the spontaneous hydrolysis of succinylcholine. 
health except for a minor surgical condition. He was total y apnoeic for almost three-quarters of an hour after the injection of $40 \mathrm{mg}$. of succinylcholine iodide. Consciousness returned before respiration. Two sera were from mental patients of Dr. Gunn from the Ontario Hospital, New Toronto. They were given succinylcholine repeatedly for electroshock treatment and Dr. Gunn used these occasions to determine the optimal dose. One of these patients required only $5 \mathrm{mg}$. of succinylcholine chloride for adequate relaxation but the apnoea lasted for 8 to 15 minutes. Ten mg. caused apnoea for 22 to 25 minutes. The second patient required $10 \mathrm{mg}$. and the duration of apnoea was similar to that of the other patent, namely between 20 and 24 minutes. In these cases with extremely low esterase activity, succinylcholne acted almost as decamethonium acts in a normal person.

There are other types of evidence which demonstrate the importance of plasma cholinesterase for the metabolism of succinylcholme. The time of apnoea can be shortened by intravenous injection of purified plasma cholinesterase $(28,29$, 30 ). The above holds, if the esterase is injected prior to the administration of succinylcholine (28). If the esterase is injected after the administration of succinylcholine, it does not terminate an existing apnoea (28). Under these circumstances, the injected esterase comes too late to guard the entrance into the tissues. Therefore, one cannot expect its full effect.

The injection of anti-cholnesterases, such as neostigmine, was repeatedly shown to mcrease the duration of action of succinylcholine (31, 32, 33, 34). Evans and co-workers (2) showed a close correlation between esterase level and duration of apnoea Foldes and co-workers (35) found a partial correlation. Among the mental patients in the Ontario Hospital, Dr. Gunn finds no correlation between esterase level and duration of apnoea, if the few exceptional cases which were reported above are disregarded. Since there is also no correlation between dose of succinylcholme and duration of apnoea, one suspects that the electroshock itself can modify the duration of action of succinylcholine to a certain extent.

A second theoretical conclusion was that the esterase in the body is not acting at its maximum capacity; in other words, that there is a reserve of esterase activity which can be utilized if the plasma concentration of succinylcholine is very high. This is confirmed by some experiments of Dr. Gunn who, on several occasions, adminstered $1000 \mathrm{mg}$. of succinylcholne chloride by rapid intravenous injection. The apnoea lasted for only a few minutes even after this extremely high dose. The esterase activity in these patients was normal. Similar observations were made by Borders and his co-workers (28) during anaesthesia.

Third, it has been presented as a theoretical deduction that succinylmonocholine accumulates regularly during contnuous infusions of succinyldicholine. The significance of this conclusion cannot be evaluated for several reasons. It is not known whether there are more effective means than the plasma cholinesterase for the detoxification of succinylmonocholine. Such factors could prevent the accumulation which the esterase would cause.

Although the esterase action permits a prediction of ratios of concentrations of the two succinylcholines, the absolute values of these concentrations are 
unknown. Furthermore, it is not known what drop of the plasma levels is necessary to terminate the relaxant actions. Thus, one cannot calculate how long the effects will persist after the termunation of a continuous infusion or intravenous injection.

It is known that roughly twenty times more succmylmonocholine than succinyldicholine is necessary to produce a desired clinical effect. In view of the possible accumulation of succinylmonocholine, however, the potency of succinylmonocholine relative to that of succinyldicholine at the human motor end-plate may be less than it appears to be from a study of intravenous injections.

Finally, we concluded that one cannot expect that all unusual reactions with succinylcholine are due to a low activity of plasma cholinesterase. During the past year, we have received several samples of normal plasma from patients with prolonged apnoea after succinylcholine. Prolonged apnoea has been reported after all muscular relaxants (36), and some factor may occasionally affect the action of succinylcholine which could also affect some other relaxant.

\section{SUMMARY}

The plasma cholinesterase of a normal adult is capable of destroying in vitro up to $120 \mathrm{mg}$. per minute of succinylcholine chlonde. This great speed of destruction cannot be obtained in vivo, yet the norral plasma cholinesterase can effectively cope with a considerable excess of succinylcholine.

The rate of destruction of succinylcholine for any given concentration of succinylcholine is proportional to the concentration of plasma cholinesterase.

On slow intravenous infusion of succinyldicholne, the plasma cholinesterase must be assumed always to cause an accumulation of succinylmonocholne so that the concentration of succinylmonocholine exceeds by about 40 times the concentration of succinyldicholine. It is not yet clear whether this accumulation of succinylmonocholine is prevented by factors other than plasma cholinesterase, or whether this accumulation escapes clinical detcction.

In order to exert its action at the neuromuscular junction, succinylcholine must enter the extravascular space where it is not exposed to plasma cholinesterase. Thus one cannot expect the esterase to be responsible for all abnormal reactions towards succinylcholine.

The sera of three patients are described, in these cholinesterase activity towards succinylcholine is too low to be measured. In all three cases the esterase has some peculiarities which are not fully explained. In one of these patients injection of $5 \mathrm{mg}$. of succinylcholine chloride was found to cause profound relaxation and 15 minutes' apnoea.

\section{ACKNOWLEDGMENTS}

I wish to take advantage of this occasion to say some words of thanks. Without stimulus from Professor J. K. W. Ferguson and Dr. R. A. Gordon this paper would not have been written. Dr. Gordon continued his help by sending samples of plasma and discussing his cases. Dr. F. F. Foldes of Pittsburgh assisted by sending his data when our supply of succinylmonocholine failed. All calculations involving succinylmonocholine are based on unpublished data by Dr. Foldes. 


\section{RÉsUMÉ}

La plasma cholinestérase d'un adulte normal peut détruire in vitro jusqu’à $120 \mathrm{mg}$. per minute de chlorure de succinylcholine. In vivo, la réaction enzymatique n'est pas si rapide parce que la concentration plasmatique de la sucrinylcholine n'est pas assez élevée pour saturer l'enzyme. En d'autres mots, la p_asma cholınestérase normale peut détruire plus de succinylcholine en peu de temps qu'il n'est nécessaire pour obtenir un effet de relâchement musculaire.

Pour une concentration donnée de sưccinylcholine, la vitesse de destruction dort être proportionnel au niveau plasmatique de la cholinestérase même si l'estérase n'agit pas à sa capacité maximum.

Lorsqu'une solution de succinyldicholıne est injectée lentement en intraveineuse, on doit toujours se rappeler que la plasma cholinestérase cause une accumulation de succinylmonocheline de sorte que la concentration de succinylmonocholine est environ 40 fors celle de la succinyldicholine. On ne connait pas encore si cette accumulation de succinylmonocholine est arrêtée par d'autres facteurs que la plasma cholmestérase ou bien si elle échappe à l'investigation clinique.

La succinylcholine agit à la jonction neuro-musculaire. Pour l'atteindre, la succinylcholine doit entrer dans le milieu extra cellulaire. Dans le liquide extravascularre la succinylcholine n'est pas au contact de la plasma cholinestérase. En d'autres mots, l'estérase previent l'entrée et la sorties dans les tissus mais ne peut être tenu responsable des irrégularités qui peuvent survenir dans les tissus au lieu d'action de la succinylcholine

Il est connu que la concentration de plasma cholinestérase varie d'une personne à une autre. Habituellement il s'agit et une variation de quantité de l'enzyme mais il peut survenir aussi des variations dans les propriétés de la plasma cholinestérase. Seulement dans trois de ces cas, l'activité de l'estérase sur la succinylcholine fût trop basse pour être mesurer. Chez l'un de ces patients, l'injection de 5 mg. de succinylcholine causa un relâchement musculaire profond et une apnée de 15 minutes.

\section{REFERENCES}

1. Bovet-Nitri, F. Degradazione di Alcune Sostanze Curarizzanti per Azione di Colinesterasi. Rend. 1st Super Sanita. 12: 138 (1949).

2. Evans, F. T., Gray, P. W. S., LemmanN, H \& SilK, E Sensitivity to Succinylcholine in relation to Serumcholnesterase Lancet 1: 1229 (1952).

3 Mendel, B. \& Rudney, H. Studies on Cholnesterase; I, Cholinesterase and Pseudocholinesterase. Biochem. J. 37 : 59 (1943).

4. Wilson, I. B. \& Conen, M. The Essentiality of Acetylcholinesterase in Conduction. Biochim. et Biophys. Acta. 11: 147 (1953).

5 Wirson, A., Calvert, R. J. \& Geogemgan, H. Plasmacholinesterase Activity in Liver Disease: Its Value as a Diagnostic Test of Liver Function compared with Flocculation Tests and Plasma Protein Determinations J. Clin. Investigation 31: 815 (1952).

6. Whittaker, V. P. Mode of Action and Distribution of Cholinesterases. Physiol. Rev. 31.312 (1951).

7. Mendel, B \& Mundeli, D. B. Studies on Cholinesterase; II, A Method for the Purification of a Pseudocholinesterase from Dog Pancreas. Biochem. J. 37: 64 (1943).

8. Ond, M. G \& Thompson, R. H. S Pseudocholinesterase Activity in the Central Nervous System Biochem. J. 51: 245 (1952). 
9. Myers, D K Studies on Cholinesterase; IX, Species Variation in the Specificity Pattern of the Pseudocholnesterases. B1ochem. J. 5i5: 67 (1953).

10. Mendel, B., Mundell, D. B. \& Rudney, H Studies on Cholnesterase, III, Specific Tests for True Cholnesterase and Pseudocholinesterase. Biochem J 37473 (1943).

11. Whitraker, V. P \& Wijesundera, S. Hydrolysis of Succinylcholine by Cholinesterase. B1ochem. J. 52.475 (1952).

12. TsujI, F. I. \& Foldes, F. F. Hydrolysis of Succinylcholne in Human Plasma. Fed. Proc. 12: 374 (1953)

13. Foldes, F F., McNall, P G \& Birch, J H The Neuromuscular Activity of Succirylmonocholine Iodıde in Anaesthetized Man. Brit. Med J. 1967 (1954).

14. Foldes, F F, Vandervort, R. S \& Shanor, S P The Fate of Succinylcholine in, Man. Anesthesiology 1611 (1955)

15. Michaelis, L. \& Menten, M. I. Die Kinetic der Invertınwirkung Biochem Zschr 49. 333 (1913)

16. Foldes, F F. Personal communication

17 Lindsay, H A \& Kalow, W. To be published.

18 Foldes, F F. \& Norton, S T. The Unnary Excretion of Succinyldicholine and Succinylmonocholine in Man Brit J Pharmacol 9385 (1954).

19. Espinosa, A M \& Artusio, J F The Dose Response Relationship and Duration of Action of Succinylcholine in Anaesthetized Man Anesthesiology 15239 (1954)

20 Fremont-Smith, K, Volwiler, W \& Woon, P A Serum Acetylcholnesterase, Its Close Correlation with Serum Albumm, and Its Limited Usefulness as a Test of Liver Function J. Lab. Clin Med 40692 (1952).

21. Colxing, K G. \& Rossiter, R J Cholnesterases, of Cerebrospinal Flud Can J Res, Sect. E. 27. 327 (1949).

22. Bourne, J G, Collner, H O J \& Somers, G F. Succinylcholine (Succinoylcholine) Muscle Relaxant of Short Action. Lancet 11225 (1952).

23. Evans, F. T, Gray, P W. S, Lehmann, H \& Silk, E Succinylcholine Lancet 2682 (1952)

24 Rem, J E \& Nent, D W Succinylcholine Apnoea Lancet 21232 (1952)

25. Forbat, A., Lemann, H \& Silk, E. Prolonged Apnoea followng Injection of Succinyldicholine Lancet 2. 1067 (1953).

26. Calvert, J, Lemmann, H., Silk, E. \& Slack, W K Prolonged Apnoea after Suxamethonium Lancet 2354 (1954)

27. Bourne, J. G Succinylcholine Lancet 2. 495 (1954).

28. Borders, $R$ W, Stephen, $G$ R, Nowill, W $K$ \& Maritin, $R$ The Interrelationship of Succinylcholine and the Blood Cholinesterases during Anesthesia Anesthesiology 16 401 ( 1955 )

29 Evans, F T, Gray, P W S, LemmanN, H \& SwK, E Effect of Pseudocholnesterase Level on Action of Succinylcholine in Man Brit Med J 1136 (1953).

30. Paton, W. D M Principles of Neuromuscular Block. Anaesthesia 8151 (1953)

31. Castillo, J. C \& DE BeER, E. J. Neuromuscular Blocking Action of Succinylcholine (Diacetylcholne) J. Pharmacol \& Exper. Therap 99. 458 (1950)

32. Bovet, D, Bovet-NitTt, F, Guarino, S, Longo, V G \& Fusco, R. Synthetıc Curanzing Agents, III, Succinylcholine and its Alphatic Derivatives Arch. internat de Pharrnacodyn. et de therap 881 (1951)

33 Low, H. \& Tanimein, E Succinylcholne, a Neuromuscular Blocking Drug, and its Synergism with Tetraethylpyrophosphate Acta Physiol. Scand. 2378 (1951).

34 Lucas, B. G B \& Mres, S Anticholnesterases and Muscle Relaxants Brit Med. J 1. 579 (1955).

35. Foldes, F F., Swerdlow, M, Lipschitz, E \& van Hees, G. Comparison of Enzymatic Hydrolysis of Suxamethonium and Suxethomurn with their Respiratory Effects Fed. Proc. 14339 (1955).

36. Drrpps, R. D. Abnormal Respiratory Response to Vanous "Curare" Drugs during Surgical Anesthesia: Incidence, Etiology, and Treatment. Ann. Surg. 137: 145 (1953). 